\title{
Pengaruh Motivasi Ekstrinsik dan Persepsi Siswa pada Perpustakaan Sekolah terhadap Hasil Belajar Bahasa Indonesia
}

\author{
Hartinie \\ Universitas Indraprasta PGRI \\ Jalan Nangka No. 58 C/TB. Simatupang, Tanjung Barat, Jakarta Selatan 12530
}

\begin{abstract}
The purpose of the study is to show the effect of the extrinsic motivation and students' perception on school library toward the result of learning Indonesian. The hypothesis includes; 1). There is a significant effect of the extrinsic motivation and students' perception on school library collectively toward the result of learning Indonesian. 2). There is a significant effect of the extrinsic motivation toward the result of learning Indonesian. 3). There is a significant effect of the students ' perception on school library toward the result of learning Indonesian. The method of the research is descriptive survey with 88 students as samples taken from the Tenth Grade of Public Vocational Senior High School in South Tangerang City. The result of the research shows that; 1). There is a significant effect of the extrinsic motivation and students' perception on school library collectively toward the result of learning Indonesian students of Public Vocational Senior High School in South Tangerang City. The significant effect was proved by the score of Sig. $=0,002<0,05$ and $F_{o}=6,919$. Both variable, the extrinsic motivation and students' perception on school library had given contribution of $14 \%$ to the result of learning Indonesian. 2). There is significant effect of the extrinsic motivation toward the result of learning Indonesian of Public Vocational Senior High School in South Tangerang City. The significant effect was proved by the score of Sig. $=0,001<0,05$ and $t_{o}=3,282$. The extrinsic motivation variable had given a contribution on the result of learning Indonesian is 10,9\%. 3). There is a significant effect of students' perception on school library toward the result of learning Indonesian of the Public Vocational Senior High School in South Tangerang City. The significant effect was proved by the score of Sig. $=0,032<0,05$ and $t_{o}=2,186$. This variable had given a contribution on the result of learning Indonesian is $3,91 \%$.
\end{abstract}

Keywords: extrinsic motivation, perception on school library, result of learning Indonesian.

\begin{abstract}
Abstrak
Tujuan penelitian untuk mengetahui Pengaruh Motivasi Ekstrinsik dan Persepsi siswa pada perpustakaan sekolah terhadap Hasil belajar bahasa Indonesia. Hipotesis penelitian ini meliputi: 1) Terdapat pengaruh yang signifikan Motivasi Ekstrinsik dan Persepsi siswa pada perpustakaan sekolah secara bersama-sama terhadap hasil belajar bahasa Indonesia, 2. Terdapat pengaruh yang signifikan Motivasi Ekstrinsik terhadap prestasi belajar bahasa Indonesia 3. Terdapat pengaruh yang signifikan Persepsi siswa pada perpustakaan sekolah terhadap Hasil belajar bahasa Indonesia. Metode penelitian yang digunakan adalah metode survey deskriptif dengan mengambil sampel sebanyak 88 siswa kelas X tahun ajaran 2018/2019 yang berasal dari tiga Sekolah Menengah Kejuaraan Negeri Kota Tangerang Selatan. Hasil Penelitian ini menunjukkan bahwa: 1) Terdapat pengaruh yang signifikan motivasi ekstrinsik dan persepsi siswa pada perpustakaan sekolah secara bersama-sama terhadap hasil belajar bahasa Indonesia. Hal ini dibuktikan dengan perolehan nilai $F_{\text {hitung }}=6,919$ dan Sig. 0,002 < 0,05. Secara bersama-sama variabel motivasi ekstrinsik dan persepsi siswa pada perpustakaan sekolah memberikan kontribusi sebesar $14 \%$ terhadap variabel hasil belajar bahasa Indonesia siswa SMK Negeri di Kota Tangerang Selatan. 2) Terdapat pengaruh yang signifikan motivasi ekstrinsik terhadap hasil belajar bahasa Indonesia. Hal ini dibuktikan dengan perolehan nilai $t_{\text {hitung }}=3,282$ dan Sig. $0,001<0,05$. Variabel motivasi ekstrinsik memberikan kontribusi sebesar 10,09 \% dalam meningkatkan hasil belajar bahasa Indonesia siswa SMK Negeri di Kota Tangerang Selatan. 3). Terdapat pengaruh yang signifikan persepsi siswa pada perpustakaan
\end{abstract}

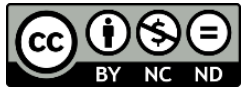




\section{Diskursus: Jurnal Pendidikan Bahasa Indonesia}

Vol. 1, No. 3, Desember 2018, pp. 220-229

p-ISSN: 2615-4935

e-ISSN: 2615-4943

sekolah terhadap hasil belajar bahasa Indonesia. Hal ini dibuktikan dengan perolehan nilai thitung $_{=}$ 2,186 dan Sig. $0,032<0,05$. Variabel persepsi siswa pada perpustakaan sekolah memberikan kontribusi sebesar 3,91 \% dalam meningkatkan hasil belajar bahasa Indonesia siswa SMK Negeri di Kota Tangerang Selatan.

Kata Kunci: Motivasi ekstrinsik, persepsi siswa pada perpustakaan sekolah, hasil belajar bahasa Indonesia

\section{PENDAHULUAN}

Bahasa Indonesia, yang merupakan bahasa nasional, memegang peranan penting dalam dunia pendidikan. Seseorang yang kemampuan bahasa Indonesianya baik akan lebih mudah meningkatkan pengetahuan dan keterampilannya. Oleh karena itu, dalam pembelajaran bahasa Indonesia di sekolah guru harus mampu membekali siswanya untuk menguasai keterampilan berbahasa Indonesia baik yang bersifat keterampilan pemahaman seperti mendengar dan membaca maupun keterampilan memproduksi seperti menulis dan berbicara.

Rendahnya hasil belajar harus menjadi perhatian bagi semua pihak yang terlibat dalam pendidikan. Berbagai faktor yang mungkin menyebabkan rendahnya prestasi belajar bahasa Indonesia perlu dicermati. Dari uraian di atas jelas terlihat bahwa prestasi belajar bahasa Indonesia siswa dipengaruhi oleh beberapa faktor, yaitu meliputi faktor internal dan eksternal. Faktor internal merupakan faktor yang berasal dari dalam diri siswa meliputi: bakat, minat, kecerdasan emosional, sikap dan keterampilan yang ada pada dirinya.

Perpustakaan sekolah sebagai sarana belajar, keberadaannya sangat dibutuhkan oleh siswa tetapi belum tentu di sekolahnya ada fasilitas tersebut. Ada atau tidaknya perpustakaan sekolah disebabkan oleh dibangun atau tidaknya sarana perpustakaan oleh pemerintah, Selama ini pemerintah baru bisa membangun sarana perpustakaan untuk sekolah negeri, sedangkan sekolah swasta membangun dengan biaya sendiri gedung perpustakaan sekolah. Pemerintah memang harus membangun perpustakaan sekolah di tiap sekolah baik negeri maupun swasta jika ingin pendidikan di Indonesia maju.

Selama ini persepsi siswa pada perpustakaan sekolah yaitu tempat tumpukan buku-buku atau gudang buku yang hanya didatangi apabila siswa disuruh meminjam buku pelajaran. Padahal sebenarnya perpustakaan sekolah tidak hanya tempat tumpukan buku-buku saja, maknanya lebih dari itu. Perpustakaan sekolah salah satu bagian dari sarana pendidikan yang ikut berperan dalam memperluas wawasan siswa. Dalam kenyataannya memang ada gejala bahwa tidak semua siswa yang berpersepsi baik terhadap perpustakaan sekolahnya hasil belajarnya memuaskan, dan sebaliknya tidak semua siswa yang berpersepsi buruk terhadap perpustakaan sekolahnya hasil belajarnya mengecewakan. Hasil belajar siswa dapat meningkat apabila siswa tersebut benar-benar memanfaatkan perpustakaan sekolah dengan sebaik-baiknya. Artinya perpustakaan sekolah sudah dimanfaatkan secara optimal, tidak hanya sekedar datang ke perpustakaan dan tidak memanfaatkan sarana yang ada di perpustakaan yang dikunjungi. Semuanya itu memang tergantung dari siswa itu sendiri, apabila dalam pemanfaatan perpustakaan sekolah

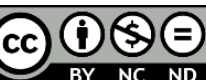

Creative Commons Attribution-NonCommercial-NoDerivatives 4.0 International License 
itu benar-benar dilaksanakan dengan sesungguhnya akan tidak mungkin apabila prestasi belajarnya tidak memuaskan. Apalagi yang dilihat adalah prestasi belajar Bahasa Indonesia. Mata pelajaran yang menurut banyak orang menuntut banyak hafalan dan kadang dianggap kurang penting jika dibandingkan dengan pelajaran lain seperti Matematika atau IPA. Padahal mata pelajaran ini justru sudah dikenalkan oleh orang tua kita sejak kita lahir, namun setelah memasuki dunia pendidikan motivasi belajar siswa terhadap bidang studi Bahasa Indonesia tidak mampu berkembang optimal.

Peranan guru juga sangat penting dalam usaha memajukan perpustakaan sekolah dan membentuk persepsi positif bagi siswa. Siswa akan lebih bersemangat apabila mendapat dukungan dari guru dalam melaksanakan tugas yang melibatkan beberapa buku yang ada di perpustakaan. Belum maksimalnya prestasi belajar Bahasa Indonesia juga dapat disebabkan oleh beberapa hal antara lain karena hanya menitikberatkan pada aspek hasil sementara aspek lain yaitu proses dan sikap peserta didik terhadap sesuatu kurang mendapat perhatian semestinya. Sangatlah komplek untuk meraih prestasi keberhasilan siswa.

Motivasi intrinsik yang ada pada diri siswa, motivasi ekstrinsik juga sangatlah penting dalam proses belajar siswa, dengan adanya motivasi ekstrinsik, siswa dapat dimotivasi diarahkan ke arah pencapaian suatu tujuan. Motivasi ekstrinsik inilah yang diharapkan penulis mampu meningkatkan hasil belajar bahasa Indonesia. Motivasi ekstrinsik dapat melibatkan guru, lingkungan sekolah, orang tua dan teman yang dapat memberikan motivasi kepada siswa agar dapat meningkatkan hasil belajar bahasa Indonesia. Jadi bagi siswa yang dalam dirinya tidak ada minat ataupun motivasi dalam belajar bahasa Indonesia, namun dengan dorongan dari orang - orang di sekitarnya diharapkan mampu membangkitkan motivasi siswa tersebut dalam belajar bahasa Indonesia. Motivasi ektrinsik dapat berupa pujian dari guru, orang tua dan teman sehingga menambah semangat siswa dalam belajar bahasa Indonesia. Nasihat dari orang-orang terdekat merupakan motivasi ekstrinsik yang mampu membuat siswa tertarik dalam belajar bahasa Indonesia. Sarana perpustakaan yang memadai, menarik juga merupakan bagian motivasi yang dapat membangkitkan minat siswa untuk belajar bahasa Indonesia.

\section{Hakikat hasil belajar bahasa Indonesia}

Sutikno (2004:3) mengartikan bahwa belajar sebagai suatu proses usaha yang dilakukan oleh seseorang untuk memperoleh suatu perubahan yang baru sebagai hasil pengalamannya sendiri dalam interaksi dengan lingkungannya. Dan pengertian tersebut dapat dikatakan bahwa hasil dari belajar ditandai dengan adanya perubahan yang terjadi dalam diri seseorang setelah melakukan kegiatan tertentu.

Belajar merupakan proses untuk memperoleh motivasi dalam pengetahuan, keterampilan, kebiasaan dan tingkah laku. Hal ini menunjukkan bahwa kegiatan belajar menjadi dasar dalam perolehan motivasi, pengetahuan, keterampilan, kebiasaan dan tingkah laku. Oleh karena itu proses belajar seharusnya dapat menjadikan siswa memiliki pengetahuan, keterampilan, kebiasaan dan tingkah laku kearah yang lebih baik.

Barnadib (2000:12) mengatakan bahwa belajar pada hakikatnya adalah belajar untuk berfikir. Berdasarkan definisi tersebut dapat diartikan bahwa belajar 
merupakan proses yang dilakukan siswa untuk melatih pikiran dan kemampuan menganalisa dan serta menelaah permasalahan yang ada. Untuk dapat menguasai pengetahuan dengan baik dibutuhkan kemampuan berfikir dan senantiasa melatih kemampuan yang telah dimiliki.

Hasil belajar mempunyai peranan penting dalam proses pembelajaran. Tujuan utama yang ingin dicapai dalam kegiatan pembelajaran adalah hasil belajar. Menurut Sudjana, pengertian hasil belajar adalah kemampuan - kemampuan yang dimiliki siswa setelah menerima pengalaman belajarnya. Menurut Susanto, pengertian hasil belajar adalah perubahan yang terjadi pada diri siswa baik yang menyangkut aspek kognitif, afektif dan psikomotorik. Jadi dapat disimpulkan hasil belajar adalah perubahan perilaku dan kemampuan secara keseluruhan yang dimiliki siswa setelah belajar, yang wujudnya berupa kemampuan kognitif, afektif dan psikomotorik yang disebabkan oleh pengalaman. Hasil belajar digunakan sebatas mana siswa memahami dan mengerti materi tersebut.

Belajar Bahasa Indonesia, mengarah kepada kemampuan bernalar dan berfikir dan bertindak akurat dalam membangun hubungan antar sesama manusia dan hubungan manusia dengan lingkungan serta hubungan manusia dengan sang pencipta Allah Swt.Pemahaman terhadap masalah dan karakteristik suatu wilayah merupakan sebuah kemampuan yang sangat dibutuhkan agar seseorang dapat eksis dalam berintegrasi dengan lingkungan dan berintegrasi dengan sesama warga masyarakat.

Untuk dapat berhasil dan sukses dalam mengikuti pembelajaran Bahasa Indonesia, tidak hanya dilakukan dengan menghapal berbagai kejadian semata, belajar Bahasa Indonesia harus diikuti oleh kegiatan aktif yang mampu mendorong untuk bertindak sesuai norma dan nilai yang berlaku dalam masyarakat. Penguasaan materi bidang studi Bahasa Indonesia didukung oleh beragam kemampuan yang saling tekait, diantaranya kemampuan memahami masalah, membangun komunikasi, menggunakan pengetahuan untuk bertindak aktif. Dalam proses belajar bahasa, ada sejumlah prinsip -prinsip yang dapat melicinkan jalan menuju keberhasilan belajar bahasa (Djamarah, 2008: 69-73 ).

\section{Hakikat Persepsi Pada Perpustakaan Sekolah}

Slameto (2003:102) menyatakan bahwa persepsi merupakan proses yang menyangkut masuknya pesan atau informasi ke dalam otak manusia, sehingga terjadi hubungan dengan lingkungannya melalui indera penglihatan, indera penciuman, indera perasa, indera pendengaran dan indera peraba. Kegiatan belajar tidak lepas dari persepsi yang berada di benak siswa. Aktivitas pembelajaran yang terjadi harus didukung oleh persepsi siswa untuk menerima materi pelajaran melalui kemampuan indera yang dimilikinya.

Persepsi adalah proses internal yang memungkinkan kita memilih, mengorganisasikan dan rnenafsirkan rangsangan dari lingkungan kita (Mulyana, 2005:167). Staton persepsi dapat didefinisikan sebagai makna yang kita pertalikan berdasarkan pengalaman masa lalu, rangsangan-rangsangan yang kita terima melalui lima indera. Menurut Webster persepsi adalah proses bagaimana rangsangan itu diseleksi, diorganisasi dan diinterprestasikan. Persepsi meliputi penginderaan (sensasi) melalui alat-alat indera kita, atensi dan intrepretasi. Persepsi 
disebut juga inti komunikasi dengan efektif. Persepsilah yang menentukan kita memilih sesuatu pesan dan mengabaikan pesan lain. Semakin tinggi derajat kesamaan persepsi antar individu, semakin mudah dan semakin sering mereka berkomunikasi dan sebagai konsekuensinya mereka sering membentuk kelompok budaya atau kelompok identitas (Mulyana 2005:168). Persepsi dibentuk oleh tiga pasang pengaruh yaitu karakteristik dari stimuli, hubungan stimuli dengan sekelilingnya, dan kondisi-kondisi di dalam dirikita sendiri. Persepsi merupakan konseling dalam psikologi. Melalui persepsilah manusia memandang dunianya. Apakah dunianya terlihat berwarna cerah, pucat, hitam, semuanya adalah persepsi manusia yang bersangkutan. Persepsi harus dibedakan dengan sensasi yang lebih bersifat fisiologis.

Pengertian perpustakaan memperoleh penghargaan yang tinggi, bukan sekadar suatu gedung yang berisi koleksi buku yang dapat dimanfaatkan oleh masyarakat. Pada tahun 1970, The American Library Association menggunakan istilah perpustakaan untuk suatu pengertian yang luas yaitu termasuk pengertian "pusat media, pusat belajar, pusat sumber pendidikan, pusat informasi, pusat dokumenstasi dan pusat rujukan ". Dalam pengertiannya yang mutakhir, seperti yang tercantum dalam Keputusan Presiden RI nomor 11, disebutkan bahwa “ perpustakaan merupakan salah satu sarana pelestarian bahan pustaka sebagai prestasi budaya dan mempunyai fungsi sebagai sumber informasi ilmu pengetahuan, teknologi dan kebudayaan dalam rangka mencerdaskan kehidupan bangsa dan menunjang pelaksanaan pembangunan nasional.

Pengertian perpustakaan sekolah adalah perpustakaan yang berada dalam suatu sekolah yang kedudukan dan tanggung jawabnya kepada kepala sekolah yang melayani sivitas akademika sekolah yang bersangkutan. Pengertian tersebut hampir sama maknanya dengan pengertian perpustakaan sekolah yang ada dalam kamus pendidikan Sutarno (2006:53) menyatakan bahwa perpustakaan sekolah adalah unit pelayanan sumber belajar yang mengelola buku-buku, bahan rekaman dan alat peraga untuk kepentingan proses belajar mengajar di sekolah.

Casson (2001) menyatakan bahwa: Dalam arti tradisional, perpustakaan adalah sebuah koleksi buku dan majalah. Walaupun dapat diartikan sebagai koleksi pribadi perseorangan, namun perpustakaan lebih umum dikenal sebagai sebuah koleksi besar yang dibiayai dan dioperasikan oleh sebuah kota atau institusi, dan dimanfaatkan oleh masyarakat yang rata-rata tidak mampu membeli sekian banyak buku atas biaya sendiri.

Buku merupakan sarana belajar dan jenis media tradisional yang dapat dipergunakan untuk mengikuti, mengenali dan mengembangkan ilmu pengetahuan dan teknologi. Melalui buku siswa dapat memperluas, memperdalam dan menyegarkan cakrawala pikiran dan pikiranya. Dalam hubungan inilah buku sekolah mempunyai kontribusi dalam usaha meratakan kesempatan memperoleh pendidikan dan meningkatkan mutu pendidikan, ini berarti bahwa perbedaan jumlah dan jenis buku yang ada di sekolah dapat mengakibatkan perbedaan mutu pendidikan di antara sekolah yang berbeda. Tetapi dengan koleksi dan penemuan media baru selain buku untuk menyimpan informasi, banyak perpustakaan kini juga merupakan tempat penyimpanan dan atau akses ke map, cetak atau prestasi seni lainnya, mikrofilm, mikrofiche, tape audio, CD, LP, tape video dan DVD, dan 
menyediakan fasilitas umum untuk mengakses gudang data CD-ROM dan internet. Lerner (1988) mengatakan bahwa Perpustakaan dapat juga diartikan sebagai kumpulan informasi yang bersifat ilmu pengetahuan, hiburan, rekreasi, dan ibadah yang merupakan kebutuhan hakiki manusia.

Sekolah merupakan salah satu tempat diterapkannya pengembangan latar prestasi belajar siswa karena sekolah merupakan tempat pendidikan formal. Pendidikan formal tersebut tidak akan dapat berjalan optimal jika tidak adanya mlingkungan belajar yang nyaman dan kondusif terpenuhi. Siswa harus mampu menumbuhkanbelajarnya yang baik untuk dapat merubah sikap tingkah laku atau prilaku pada diri masing-masing dan dapat meraih prestasi yang tinggi. Sekolah hendaknya dapat menerapkan lingkungan belajar yang kondusif dan nyaman bagi siwa-siswanya, sehingga siswa merasa nyaman belajar ditempat tersebut.

\section{Hakikat motivasi belajar}

Motivasi sebagai suatu keadaan atau kondisi yang timbul dari dalam diri seseorang. Motivasi ini memberikan pengaruh pada persepsi agar seseorang dapat melakukan kegiatan. Motive dan motivasi merupakan dua hal yang tidak dapat dipisahkan . Motivasi merupakan penjelmaan dari motive yang dapat di lihat dari prilaku yang ditunjukkan seseorang. Hilgard mengatakan bahwa motivasi adalah suatu keadaan yang terdapat dalam diri seseorang yang menyebabkan seseorang mempunyai keinginan melakukan suatu kegiatan tertentu untuk mencapai tujuan tertentu.

Menurut Hamalik (2003:87), motivasi memiliki dua komponen luar dan komponen dalam.Komponen luar adalah apa yang diinginkan seseorang, tujuanlah yang menjadi arah kelakuannya. Sedangkan komponen dalam adalah perubahan di dalam diri seseorang, keadaan tidak puas,ketegangan psikologis. Menurut Freud (1990:133) perilaku manusia di motivasi terutama oleh insting (dorongan) dari dalam dan bagian dari ketidaksadaran psikologi manusia (alam tak sadar). Dorongan dari alam tak sadar itu (unconsciousness) adalah kehendak untuk memaksimumkan kenikmatan (termasuk kenikmatan seksual) dan kehendakuntuk menghindari kesengsaraan (pain aviodance).

Dalam menjalankan tugasnya sehari-hari, seringkali guru harus berhadapan dengan hasil belajar siswa- siswanya yang tidak sesuai dengan harapan guru ataupun hasil belajar masih di bawah ketuntasan minimal. Hasil belajar yang tidak sesuai harapan bisa saja disebabkan karena kemampuan kognitif siswa yang masih kurang, namun bisa jadi dikarenakan siswa belum termotivasi dengan baik dalam proses belajar. Dalam proses belajar motivasi sangat diperlukan, sebab seseorang yang tidak mempunyai motivasi dalam belajar tak akan mungkin melakukan aktivitas belajar. Hal ini merupakan pertanda bahwa sesuatu yang akan dikerjakan itu tidak menyentuh kebutuhannya.

Mc. Donald mengatakan bahwa motivasi adalah suatu perubahan energi di dalam pribadi seseorang yang ditandai dengan timbulnya afektif (perasaan) dan reaksi untuk mencapai tujuan (Djamarah, 2008:148). Perubahan energi dalam diri seseorang itu berbentuk suatu aktivitas nyata berupa kegiatan fisik. Karena seseorang mempunyai tujuan tertentu dari aktivitasnya, maka seseorang 
mempunyai motivasi yang kuat untuk mencapainya dengan segala upaya yang dapat dia lakukan untuk mencapainya.

\section{METODE}

Metode penelitian yang digunakan adalah metode survey deskriptif. "Metode survey deskriptif adalah suatu metode penelitian yang mengambil sampel dari suatu populasi dan menggunakan kuesioner sebagai alat pengumpulan data" (Ridwan, 2009: 65). "Kuesioner adalah sejumlah pertanyaan tertulis yang digunakan untuk memperoleh informasi dari responden dalam arti laporan tentang pribadinya atau hal-hal yang ia ketahui" (Arikunto, 2006: 151). Data dari hasil kuesioner kemudian dianalisis secara deskriptif.

Metode penelitian survey adalah usaha pengamatan untuk mendapatkan keterangan-keterangan yang jelas terhadap suatu masalah tertentu dalam suatu penelitian dilakukan secara meluas dan berusaha mencari hasil yang segera dapat dipergunakan untuk suatu tindakan yang sifatnya deskriptif yaitu menggambarkan hal-hal yang mengandung fakta-fakta, klasifikasi dan pengukuran. Hal yang akan diukur adalah fakta yang fungsinya merumuskan dan melukiskan apa yang terjadi. Tujuan penelitian deskriptif ini untuk membuat deskripsi, gambaran atau lukisan secara sistematik, faktual dan akurat mengenai fakta-fakta serta hubungan antara fenomena yang diselidiki.

\section{HASIL DAN PEMBAHASAN}

\section{Hasil}

Dari tabel dapat dinyatakan bahwa terdapat pengaruh yang signifikan motivasi ekstrinsik dan persepsi siswa pada perpustakaan sekolah secara bersamasama terhadap hasil belajar bahasa Indonesia. Hal ini dibuktikan dengan perolehan nilai Sig. $0,002<0,05$ dan $F_{\text {hitung }}=6,919$. Sementara itu, persamaan garis regresi ganda dapat dinyatakan dengan $\hat{Y}=51,001+0,454 \mathrm{XI}+0,244 \mathrm{X} 2$. Hal ini memiliki pengertian bahwa kenaikan nilai variabel motivasi ekstrinsik dan persepsi siswa pada perpustakaan sekolah memberikan kontribusi sebesar 0,454 oleh Xl dan 0,244 oleh X2 kepada variabel hasil belajar bahasa Indonesia. Pada tabel 1 menjelaskan bahwa secara bersama-sama variable motivasi ekstrinsik dan persepsi siswa pada perpustakaan sekolah memberikan kontribusi sebesar 14\% kepada variabel hasil belajar bahasa Indonesia.

Dari tabel 3 dapat dinyatakan bahwa terdapat pengaruh yang signifikan motivasi ekstrinsik terhadap hasil belajar bahasa Indonesia. Hal ini dibuktikan dengan perolehan nilai Sig.0,001 $<0,05$ dan thitung $=3,282$. Adapun kontribusi variabel motivasi ekstrinsik kepada hasil belajar bahasa Indonesia dapat dinyatakan dengan rumus:

$$
\begin{aligned}
& \mathrm{KD}=\text { Nilai } \beta X 1 Y \times \text { NilaiKorelasiPasialnya }\left(r_{\mathrm{X} 1 \mathrm{Y}}\right) \mathrm{X} 100 \% \\
& \mathrm{KD}=0,333 \times 0,303 \times 100 \%=10,09 \% \\
& \text { Dari hasil perhitungan di atas dapat dinyatakan bahwa kontribusi }
\end{aligned}
$$


motivasi ekstrinsik dalam meningkatkan prestasi belajar bahasa Indonesia sebesar $10,09 \%$

Dari tabel 3. Dapat dinyatakan bahwa terdapat pengaruh yang signifikan persepsi siswa pada perpustakaan sekolah terhadap hasil belajar bahasa Indonesia. Hal ini dibuktikan dengan perolehan nilai Sig.0,032 $<0,05$ dan $t_{\text {hitung }}=2,186$. Adapun kontribusi variabel persepsi siswa pada perpustakaan sekolah kepada prestasi belajar bahasa Indonesia dinyatakan dengan rumus:

$\mathrm{KD}=\mathrm{Nilai} \beta_{X 2 Y} \mathrm{XNilai}$ Korelasi Parsialnya $\left(r_{x 2 y}\right) \mathrm{X} 100 \%$

$\mathrm{KD}=0,222 \times 0,176 \times 100 \%=3,91 \%$

Dari hasil perhitungan di atas dapat dinyatakan bahwa kontribusi persepsi siswa pada perpustakaan sekolah dalam meningkatkan prestasi belajar bahasa Indonesua sebesar 3,91\%.

\section{Pembahasan}

Pengaruh motivasi ekstrinsik dan persepsi siswa pada perpustakaan sekolah secara bersama-sama terhadap hasil belajar bahasa Indonesia.

Hasil penelitian di atas menyimpulkan bahwa motivasi ekstrinsik dan persepsi siswa pada perpustakaan sekolah secara bersama-sama telah memberikan pengaruh positif terhadap peningkatan hasil belajar bahasa Indonesia siswa SMK Negeri di Kota Tangerang Selatan. Hal ini mengandung arti bahwa motivasi ekstrinsik dan persepsi siswa pada perpustakaan sekolah telah memberikan pengaruh yang signifikan terhadap peningkatan hasil belajar siswa SMK Negeri di Kota Tangerang Selatan.

Motivasi ekstrinsik yang dimiliki siswa sangat berpengaruh terhadap hasil belajar, karena motivasi mendorong tindakan seorang terhadap apa yang dihadapinya. Fungsi motivasi adalah sebagai pendorong usaha dan pencapaian prestasi belajar. Seseorang melakukan usaha karena adanya motivasi. Hal ini sejalan dengan Sardiman AM (2001:85) yang menyatakan bahwa adanya motivasi yang baik akan menunjukkan belajar yang baik.

Fungsi perpustakaan di sekolah adalah untuk memantapkan pengetahuan serta memupuk gemar membaca, meneliti dan mengembangkan pengetahuan. Hal itu juga sejajar dengan fungsi perpustakaan kecil di rumah. Kebanyakan orang tua meskipun mempunyai rumah berukuran besar, tidak sedikitpun terfikir untuk membuat perpustakaan kecil agar anaknya belajar dengan nyaman dan penuh motivasi. Perpustakan yang lengkap dan nyaman dapat mendorong siswa untuk memanfaatkannya.

Siswa yang memiliki motivasi ekstrinsik akan secara suka rela memanfaatkan perpustakaan sekolah. Begitu juga perpustakan sekolah yang lengkap dan nyaman akan memotivasi siswa untuk melakukan kegiatan-kegiatan belajar seperti menambah pengetahuan, mengulang pelajaran dan bahkan melakukan penelitian. Hal tersebut sesuai dengan hasil penelitian ini bahwa motivasi ekstrinsik dan persepsi siswa pada perpustakaan sekolah secara bersamasama terhadap hasil belajar bahasa Indonesia. 


\section{Pengaruh Motivasi Ekstrinsik terhadap Hasil Belajar bahasa Indonesia.}

Dari hasil penelitian dan teori yang ada dapat disimpulkan bahwa motivasi ekstrinsik telah memberikan pengaruh positif terhadap peningkatan hasil belajar bahasa Indonesia siswa SMK Negeri di Kota Tangerang Selatan. Artinya, adanya motivasi ekstrinsik telah memberikan pengaruh positif terhadap peningkatan hasil belajar bahasa Indonesia siswa SMK Negeri di Kota Tangerang Selatan.

Menggerakkan motivasi ekstrinsik dapat mendorong pencapaian hasil belajar secara optimal. Walaupun siswa mempunyai bakat dan minat yang tinggi tetapi bila tidak disertai dengan motivasi belajar yang tinggi maka hasil belajar tidak akan optimal begitu juga sebaliknya. Bisa juga siswa yang mempunyai intelegensi tinggi boleh jadi gagal karena kekurangan motivasi. Sehingga motivasi mempunyai peranan penting dalam kegiatan belajar karena motivasi adalah tenaga yang menggerakkan dan mengarahkan seseorang.

Fungsi motivasi adalah sebagai pendorong usaha dan pencapaian prestasi belajar. Seseorang melakukan usaha karena adanya motivasi. Dengan motivasi ekstrinsik siswa akan dengan suka rela memanfaatkan perpustakaan sekolah untuk menambah dan mengulang pengetahuan yang telah dipelajari di dalam kelas. Siswa yang sering membaca tentu saja dapat meningkatkan pengetahuannya termasuk bahasa Indonesia. Hal tersebut sejalan dengan hasil penelitian bahwa motivasi ekstrinsik berpengaruh terhadap pencapaian hasil belajar bahasa Indonesia.

\section{Pengaruh persepsi siswa pada perpustakaan sekolah terhadap hasil belajar bahasa Indonesia.}

Hasil penelitian di atas menyimpulkan bahwa persepsi siswa pada perpustakaan sekolah telah memberikan pengaruh positif terhadap peningkatan hasil belajar bahasa Indonesia siswa SMK Negeri di Kota Tangerang Selatan. Hal ini mengandung arti bahwa persepsi siswa pada perpustakaan sekolah memberikan pengaruh yang cukup signifikan terhadap peningkatan prestasi belajar bahasa Indonesia siswa SMK Negeri di Kota Tangerang Selatan.

Pemanfaatan perpustakaan adalah aktivitas siswa untuk menggunakan sarana-sarana belajar yang telah tersedia dengan sebaik-baiknya guna meningkatkan prestasi belajarnya. Pemanfaatan perpustakaan dapat berupa usaha siswa untuk membaca buku-buku perpustakaan, majalah, surat kabar, novel, cerpen yang berisi pelajaran Bahasa Indonesia. Tersedianya perpustakaan di sekolah berpengaruh juga terhadap minat siswa untuk mendatangi perpustakaan sekolah. Semakin lengkap dan nyaman suatu perpustakan semakin memotivasi siswa pula untuk memanfaatkan sarana perpustakaan tersebut.

Untuk mencapai prestasi belajar Bahasa Indnesia yang baik, dibutuhkan sarana belajar seperti perpustakaan yang memadai, buku pelajaran, serta fasilitas belajar lainnya. Pernyataan ini tersirat dalam pendapat yang dikemukakan oleh Surakhmad (1982:24) yaitu: pencapaian tujuan dapat diwujudkan lebih baik dengan mempergunakan sarana atau alat-alat bantu yang sesuai dengan tujuan.

Jadi berdasarkan teori di atas persepsi atas perpustakaan sekolah adalah proses aktif dari siswa dalam mengenali, memahami, mengelompokkan serta memberi makna pada pemanfaatan unit pelayanan sumber belajar yang mengelola 
buku-buku, bahan rekaman dan alat-alat peraga untuk kepentingan proses belajar mengajar di sekolah. Denga seringnya memanfaatkan perpustakan sekolah tentu saja akan menambah pengetahuan dan mempertajam pemahaman. Hal inilah yang berpengaruh terhadap hasil belajar bahasa Indonesia.

\section{SIMPULAN}

Pada bagian kesimpulan ini, penulis uraikan secara singkat hasil penelitian yang diperoleh di lapangan, yaitu tterdapat pengaruh yang signifikan motivasi ekstrinsik dan persepsi siswa pada perpustakaan sekolah secara bersama-sama terhadap hasil belajar bahasa Indonesia. Penulis ingin memberikan saran-saran yang mudahmudahan dapat bermanfaat bagi khalayak banyak, yaitu: 1) Seorang guru selain dituntut untuk meningkatkan kompetensinya, juga dituntut untuk dapat meningkatkan menciptakan motivasi ekstrinsik para siswanya. Motivasi ekstrinsik yang dimiliki siswa sangat berpengaruh terhadap hasil belajar, karena motivasilah yang mendorong seorang siswa untuk melakukan kegiatan belajar secara sungguhsungguh. 2) Kepala Sekolah senantiasa memperhatikan dan meningkatkan fasilitas dan kenyamanan perpustakaannya, mengingat perpustakaan merupakan sumber ilmu pengetahuan dan tempat siswa untuk menumbuhkan minat bacanya, Dengan fasilitas perpustakaan yang lengkap dan nyaman diharapkan seluruh siswa mau memanfaatkan sarana belajar tersebut. 3) Bagi orang tua yang mampu, akan lebih baik apabila dapat menyediakan perpustakaan kecil di rumahnya. Di samping membudayakan kegiatan membaca siswa tersebut juga terdorong untuk belajar di rumah.

\section{DAFTAR PUSTAKA}

Arikunto, S. (2006). Dasar-dasar evaluasi pendidikan. Jakatra: Bumi Aksara.

Barnadib, S. I. (2000). Ilmu Pendidikan Teoritis dan Praktis. Yogyakarta: F.P Yogyakarta

Casson, R. et al. (2001). The Miami University Digital Library: A whitepaper.

Djamarah, B.S. (2008). Psikologi belajar. Jakarta : PT Rineka Cipta

Hamalik, O, (2003). Proses belajar dan mengajar. Jakarta: PT. Bumi Aksara.

Lerner, T. C., (1988). Learning disabilities: Theories, diagnosis, and teaching strategies. Boston: Huoghton Mufflin.

Mulyana, D. (2005). Ilmu komunikasi: Suatu pengantar. Bandung: Remaja Rosdakarya.

Sardiman, A. M. (2001). Interaksi dan motivasi belajar mengajar. Jakarta: Grafindo.

Slameto. (2003). Belajar dan faktor-faktor yang memengaruhinya. Jakarta: Rineka Cipta.

Sutarno, N. S. (2006). Perpustakaan dan masyarakat. Jakarta: Sagung Seto.

Sutarno, N.S. (2003). Perpustakaan dan Masyarakat. Jakarta: Yayasan Obor Indonesia.

Sutikno, M. S. (2004). Belajar dan pembelajaran. Bandung: Prospect. 